$\xi=-1$

\title{
Development of quaternary blended high performance concrete made with high reactivity metakaolin
}

\author{
V Srinivasa Reddy ${ }^{1}, \mathbf{R}$ Nirmala $^{2}$ \\ Professor of Civil Engineering, GRIET Hyderabad, \\ M.Tech Student, Department of Civil Engineering (Structural Engg.), GRIET Hyderabad \\ *author E-mail:: vempada@gmail.com
}

\begin{abstract}
In the last three decades, supplementary cementitious materials such as fly ash, silica fume and ground granulated blast furn ace slag have been judiciously utilized as cement replacement materials as these can significantly enhance the strength and durability characteristics of concrete in comparison with ordinary Portland cement (OPC) alone. Hence, high-performance concretes can be produced at lower water/powder ratios by incorporating these supplementary materials. One of the main objectives of the present research work was to investigate synergistic action of binary, ternary and quaternary blended high strength grade (M80) concretes on its compressive strength. For blended high strength grade (M80) concrete mixes the optimum combinations are: Binary blend (95\%OPC $+5 \%$ FA, $95 \% \mathrm{OPC}+5 \% \mathrm{MS}$ and $95 \% \mathrm{OPC}+5 \% \mathrm{MK})$, ternary blend $(65 \% \mathrm{OPC}+20 \% \mathrm{FA}+15 \% \mathrm{MS})$ and quaternary blend $(50 \% \mathrm{OPC}+28 \% \mathrm{FA}+11 \% \mathrm{MS}+11 \% \mathrm{MK})$. Use of metakaolin in fly ash based blended concretes enhances compressive strength significantly and found to be cost effective in terms of less cement usage, increased usage of fly ash and also plays a major role in early strength development of fly ash based blended concrete.
\end{abstract}

Keywords: high performance Concrete, Metakaolin, Fly ash, quaternary blended concrete, high strength concrete..

\section{Introduction}

One of the effective methods to conserve the Mother Nature's resources and also reduce the environmental impact is to use Supplementary Cementitious Materials (SCMs) by substituting OPC partly or totally in concrete. Since most of SCMs are pozzolanic in nature and hence they are helpful in increasing later strength of concrete [1][2][4]. Blending of SCMs with cement has many advantages such as saving in cement, utilization of industrial byproducts, enhancement of micro structural properties of concrete and reduces environmental impact through reduced greenhouse gases production. Most of the SCMs are industrial by-products which are considered as waste and pollutants when dumped into land or thrown into water bodies. So blending them in concrete becomes safe disposal method for them. Such SCMs are Fly ash (FA), Ground Granulated Blast furnace Slag (GGBS), Micro Silica(MS) or Silica Fume(SF), Copper slag (CS), Rice Husk Ash (RHA) etc.[3]

\section{Objectives of the Present work}

The primary objectives of this research work is to quantitatively comprehend and assess the role of optimum metakaolin (MK) in development of strength in binary, ternary and quaternary blended concrete, made with optimal micro silica and fly ash, of High strength grade (M80).

\section{Experimental Investigations}

The aim of the present experimental investigations is aimed to obtain specific experimental data which helps to understand the effect of synergic action of Metakaolin (MK), Microsilica (MS) and fly ash (FA) combinations in blended concrete mixes of high strength grade (M80) on rheological behavior and strength. The experimental programme consisted of casting and testing specimens of high strength grade (M80) of binary, ternary and quaternary blended concretes made with Fly Ash (FA), Microsilica (MS) and Metakaolin (MK). Erntroy and shaklock empirical mix design was adopted to arrive at the suitable mix proportions and final quantities for the binary, ternary and quaternary blended concrete based on a number of trial mixes.

To accomplish the defined objectives, the scope of the work is framed into phases:

Phase 1: Physical and Chemical Properties of Materials Used

a) Studies on physical and chemical properties of cement, coarse aggregate, fine aggregate (river sand), mixing water.

b) Studies on physical and chemical properties of mineral admixtures such as fly ash, metakaolin, silica fume and that of chemical admixtures such as Superplasticizer.

Phase 2: Determination of Mix Proportions

Based on Entroy and Shacklock's empirical graphs, material quantities such as powder content (Cement + Pozzolan), fine aggregate, coarse aggregate, water and dosages of SP, required for $1 \mathrm{cu} . \mathrm{m}$, are evaluated for High strength grade (M80) of concrete. Final quantities, for the above grade of concrete mixes considered, are assumed after several trial mixes on material quantities computed. Phase 3: Optimization of pozzolans in concrete mixes In the first part of this phase, based on the assumed final material quantities in Phase 2, the optimum proportions of fly ash (FA), micro silica (MS) and metakaolin (MK) combinations in binary, ternary and quaternary blended concrete mixes, that attain desired strength property, are identified through several trial mixes carried 
out in the laboratory for the grade considered for study.[5][6][7][8][9]\&[10].

Phase 4: Studies on Compressive Strength

Compressive strengths at 3, 7, 28 and 60 days were determined by conducting detailed laboratory investigations on high strength grade (M80) made with optimum quantities of FA, MS and MK combinations in binary, ternary and quaternary blended concrete mixes.

\section{Materials Used}

\subsection{Cement}

Ordinary Portland cement (OPC) of 53 grade [IS: 12269-1987, Specifications for 53 Grade Ordinary Portland cement] has been used in the study.

\subsection{Fine Aggregates (River Sand)}

The fine aggregate used was locally available river sand without any organic impurities and conforming to IS: $383-1970$.

\subsection{Coarse Aggregate}

The coarse aggregate chosen for blended concrete was typically round in shape, crushed granite metal of size of $20 \mathrm{~mm}$ and $10 \mathrm{~mm}$ graded obtained from the locally available quarries was used in the present investigation.

\subsection{Water}

Water used for mixing and curing was potable water, which was free from any amounts of oils, acids, alkalis, sugar, salts and organic materials or other substances that may be deleterious to concrete or steel confirming to IS : 3025 - 1964 part22, part 23 and IS : 456 - 2000 [Code of practice for plain and reinforced concrete].

\subsection{Fly Ash}

Fly ash used in this investigation was procured from Vijayawada Thermal Power Station, Andhra Pradesh, India. It confirms with grade I of IS: 3812 - 1981 [Specifications for flyash for use as pozzolana and admixture].

\subsection{Micro silica (MS)}

Micro silica Grade 92D conforming to IS: 15388 -2003 is used. Silica fume has specific surface area of about $20,000 \mathrm{~m}^{2} / \mathrm{kg}$.

\subsection{Metakaolin (MK)}

Metakaolin obtained from KOAT manufacturing company, Vadodara, Gujarat has been used.

\subsection{Super Plasticizer (SP)}

For M80, BASF Glenium B233, High-performance super plasticizer based on PCE (polycarboxylic ether) for concrete conforming to IS: $9103-1999$ is used as a water-reducing admixture.

\section{Mix Proportioning}

The mix proportioning was done based on the Erntroy and shaklock mix design approach for high strength grade (M80) of binary, ternary and quaternary blended concretes made with optimum combinations of fly ash (FA), microsilica (MS) and metakaolin(MK). Several trial mixes are conducted on number of blended concrete mixes made with the different possible combinations of Fly Ash (FA), Microsilica (MS) and Metakaolin (MK) to develop various binary, ternary and quaternary blended concrete systems to determine the appropriate optimized quantities of Fly Ash.

\section{Test Results and Discussions}

The test results of experimental investigations carried out during the development of high strength grade (M80) binary, ternary and quaternary blended concrete mixes made with optimum proportions of fly ash (FA), microsilica (MS) and metakaolin (MK) combination are tabulated in the following sections. Quantities required for 1 cu.m are evaluated for high strength grade (M80) binary, ternary and quaternary blended concretes made with optimum proportions of Fly Ash (FA), Microsilica (MS) and Metakaolin (MK) combination based on calculations from Erntroy and shacklock mix design method. Final quantities, for all blended concrete mixes considered, are assumed after several trial mixes on quantities computed

Table 1. Quantities in kg per cu.m for high strength (M80) grade blended concrete obtained using Erntroy and shacklock Mix Design

\begin{tabular}{|l|l|l|l|l|}
\hline & Cement & $\begin{array}{l}\text { Fine Aggre- } \\
\text { gate }\end{array}$ & $\begin{array}{l}\text { Coarse Aggre- } \\
\text { gate }\end{array}$ & Water \\
\hline $\begin{array}{l}\text { Quantity } \\
\mathrm{kg} / \mathrm{m}^{3}\end{array}$ & 700 & 644 & 966 & $150 \mathrm{~L}$ \\
\hline
\end{tabular}

The computed amount of OPC is $700 \mathrm{~kg}$. But keeping in view the clause 8.2.4.2 of IS 456-2000, the maximum cement content is limited to $450 \mathrm{~kg}$ per cum of concrete. After trail mixes, revised quantities in kg per cu.m for high strength grade (M80) blended concrete mix are arrived without compromising the desired strength property.

The final quantities for high strength M80 grade blended concrete mix are tabulated in Table 2 .

Table 2: Final Quantities for trial mixes of high strength M80 grade blended concrete mix

\begin{tabular}{|l|l|l|l|l|l|l|}
\hline & $\begin{array}{l}\text { Ce- } \\
\text { ment }\end{array}$ & $\begin{array}{l}\text { Total } \\
\text { Pozzo- } \\
\text { lana }\end{array}$ & $\begin{array}{l}\text { Total } \\
\text { Pow- } \\
\text { der } \\
\text { Con- } \\
\text { tent }\end{array}$ & $\begin{array}{l}\text { Fine } \\
\text { Aggre- } \\
\text { gate }\end{array}$ & $\begin{array}{l}\text { Coarse } \\
\text { Aggre- } \\
\text { gate }\end{array}$ & $\begin{array}{l}\text { Water } \\
\text { (wa- } \\
\text { ter/powder } \\
=0.23)\end{array}$ \\
\hline $\begin{array}{l}\text { Quan- } \\
\text { tity } \\
\mathrm{kg} / \mathrm{m}^{3}\end{array}$ & 450 & 250 & 700 & 644 & 966 & $150 \mathrm{~L}$ \\
\hline
\end{tabular}

Henceforth, the total amount of powder quantity (cement + pozzolanic mixture) adopted for high strength M80 concrete is 700 $\mathrm{kg} / \mathrm{m}^{3}$ and water/powder ratio is 0.23 for all blended high strength M80 concrete mixes.

\subsection{Optimization of SCMs proportions in blended concrete mixes}

This phase identifies the optimum proportions of fly ash, micro silica and metakaolin in binary, ternary and quaternary blended concrete mixes in order to obtain the enhanced performance of blended concrete at all ages. The details of the quantities of materials, replacement percentages and quantities $(\mathrm{kg})$ of SCMs and OPC in total powder content and their corresponding fresh properties are shown in Table 3 to Table 4 respectively for high strength grade (M80) of binary, ternary and quaternary blended concrete made with optimum proportions of Fly Ash (FA), Microsilica (MS) and Metakaolin (MK) combination.

Table 3 gives base quantities of high strength grade (M80) blended concrete mix derived after several trial mixes on the quantities calculated using Erntroy and shacklock mix design method. It can be observed that the total powder content is $700 \mathrm{~kg} / \mathrm{m} 3$ with cement content restricted to $450 \mathrm{~kg} / \mathrm{m} 3$ from durability of concrete point of view and rest of the powder is fly ash $(250 \mathrm{~kg} / \mathrm{m} 3)$. Depending on the above calculated base quantities for high strength 
grade (M80), twenty nine (29) blended concrete mixes were designed in three groups of binary, ternary and quaternary. Table 2 shows various blended high strength grade (M80) blended concrete mixtures made with different proportions of Fly Ash (FA), Microsilica (MS) and Metakaolin (MK). In Mix designation, number indicates percentage by weight of total powder content. Various binary, ternary and quaternary blended concrete mixes were prepared with different proportions of Fly Ash (FA), Microsilica (MS) and Metakaolin (MK). (B1 to B8, T1 to T8 and Q1 to Q12). Mix numbers B1 to B8 are binary blended concrete mixtures made of either fly ash (FA) or microsilica (MS) or metakaolin (MK) while Mix numbers T1 to T8 are ternary blended fly ash based concrete mixtures made of microsilica (MS) or metakaolin (MK) and Mix numbers Q1 to Q12 are quaternary blended fly ash based concrete mixtures made of microsilica (MS) and metakaolin (MK) combination.

In high strength grade (M80) concrete mix ' $\mathrm{C} 1$ ' developed with $100 \%$ OPC does not yield desired strength. So using 100\% OPC in development of high strength grade (M80) concrete mix is completely ruled out. In binary blended high strength grade (M80) concrete mixtures, percentage replacement of fly ash by weight of total powder content is $35 \%$ i.e. $250 \mathrm{~kg} / \mathrm{m} 3$ (B1) which is based on preliminary calculation from mix design. For the mix proportion C65+FA35, desired strength is not realized. For binary blended concrete mixtures made with percentage replacement of either micro silica (MS) or metakaolin (MK) or both combined, micro silica (MS) and metakaolin (MK) are limited to $5-15 \%$ and $5-20 \%$ respectively.

In ternary blended micro silica (MS) and fly ash (FA) blended high strength grade (M80) concrete mixtures (T1 to T4) percentage replacement of micro silica (MS) is limited to $5-20 \%$ by weight of total powder content. Similarly in ternary blended metakaolin (MK) and fly ash (FA) blended high strength grade (M80) concrete mixtures (T5 to T8), percentage replacement of metakaolin (MK) is limited to $5-20 \%$ by weight of total powder content. In both the above ternary blended MS+FA blended concrete and $\mathrm{MK}+\mathrm{FA}$ blended concrete mixtures (T1 to $\mathrm{T} 8$ ), the cement content is kept constant ( $65 \%$ by weight of total powder content). In binary blended high strength grade (M80), for fly ash (FA) blended concrete mix (B1) and metakaolin (MK) blended concrete mixes (B5 to B8) desired strength is not realized. But in binary blended micro silica (MS) blended concrete mix, desired strength is attained, if the MS percentage replacement is limited to 5-10\% by weight of powder. The optimal mix chosen for binary blended micro silica (MS) based concrete mix is 5\% MS replacement (B2). Henceforth, for high strength grade (M80) mixes, Mix OPC95+MS5 (B2) is taken as reference mix.

In ternary blended metakaolin (MK) and fly ash (FA) blended high strength grade (M80) concrete mixtures (T5 to T8), desired strengths are not obtained for any of the mixes. But for micro silica (MS) and fly ash (FA) blended ternary blended concrete mixes (T1 toT4), up to $15 \%$ MS by weight of powder, desired strengths are attained satisfactorily. So C65+FA20+MS15 (T3) concrete mix is considered optimal in ternary blended high strength grade (M80) concrete mixes.

In quaternary blended high strength grade (M80) concrete mixtures (Q1 to Q12) made of microsilica (MS) and metakaolin (MK) combination, keeping cement content constant ( $65 \%$ by weight of total powder content), microsilica (MS) and metakaolin (MK) proportions are limited to $7-14 \%$.

For quaternary blended concrete mix (Q1), initially $7 \%$ MS and $7 \%$ MK replacements are assumed, keeping cement content constant i.e. $65 \%$ by weight of total powder content and rest of powder is fly ash, and required workability is not satisfied. So microsilica (MS) and metakaolin (MK) are gradually increased to $14 \%$ each yet workability is not achieved. Then author proposed to additionally increase fly ash content incrementally by $10 \%$ by weight of powder content $\left(700 \mathrm{~kg} / \mathrm{m}^{3}\right)$, thereby incrementally increasing the powder quantity by $70 \mathrm{~kg}$. With addition of $30 \%$ of fly ash (FA) to the C65+FA7+MS14+MK14 concrete mix (Q11), required workability and strength properties are achieved. So for quaternary blended concrete mix, the optimum combination of cement and pozzolanic mixture is revised as C50+FA28+MS11+MK11 concrete mix where final total powder content is $910 \mathrm{~kg} / \mathrm{m}^{3}$ in which cement content is $455 \mathrm{~kg} / \mathrm{m}^{3}$ and pozzolanic mixture is $455 \mathrm{~kg} / \mathrm{m}^{3}$.

Table 4 presents several possible binary, ternary and quaternary blended high strength grade (M80) concrete mixes with the quantities of pozzolanic mixtures, their flow properties and achieved strengths. From this table, three optimally blended concrete mixes are selected.

From the experimental investigations, the mixes B2, T3 and Q11 are chosen as optimum binary, ternary and quaternary blended high strength grade (M80) concrete mixes made with fly ash (FA), microsilica (MS) and metakaolin (MK) where both desired workability and strength properties are met along with optimal usage of pozzolanic quantities. The following are mix designations of optimum combinations of binary, ternary and quaternary blended high strength grade (M80) desired mixes:

\section{(1) C95+MS5 [B2] \\ (2) C65+FA20+MS15 [T3] \\ (3) $\mathrm{C} 50+\mathrm{FA} 28+\mathrm{MS} 11+\mathrm{MK} 11[\mathrm{Q} 11]$}

Numbers in the above mix designations indicate percentage by weight of total powder content. Total powder content for binary, ternary is $700 \mathrm{~kg} / \mathrm{m} 3$ and while for quaternary blended high strength grade (M80) it is $910 \mathrm{~kg} / \mathrm{m} 3$. Thus, by incorporating metakaolin (MK) into micro silica (MS) and fly ash (FA) blended ternary blended desired mixes, the amount of fly ash used has almost doubled to achieve the requisite workability and therefore desired strength. From this observation, it can be understood that micro silica (MS) in blended desired mixtures imparts high strength but flow properties are marginally satisfied while metakaolin (MK) inclusion enhances the usage of high quantity of fly ash in blended concrete mixes for superior rate of gain of strength and more importantly for improved workability of concrete mix. The quaternary blended fly ash based concrete mix made of microsilica (MS) and metakaolin (MK) combination is found to be superior to ternary blended fly ash based concrete mix made with either microsilica (MS) or metakaolin (MK) due to reasons that for similar strength, better early strength, enhanced rate of gain of strength, improved flow properties and more use of fly ash quantity in developing blended high strength grade (M80) concrete.

Table 3. Base Quantities for high strength M80 grade concrete mix

\begin{tabular}{|l|l|l|l|l|l|l|}
\hline & $\begin{array}{l}\text { Ce- } \\
\text { ment }\end{array}$ & $\begin{array}{l}\text { Fly } \\
\text { ash }\end{array}$ & $\begin{array}{l}\text { Total } \\
\text { Powder } \\
\text { Content }\end{array}$ & $\begin{array}{l}\text { Fine } \\
\text { Aggre- } \\
\text { gate }\end{array}$ & $\begin{array}{l}\text { Coarse } \\
\text { Aggre- } \\
\text { gate }\end{array}$ & \begin{tabular}{l}
$\begin{array}{l}\text { Water } \\
\text { (wa- } \\
\text { ter/powde } \\
\text { r=0.23) }\end{array}$ \\
\hline $\begin{array}{l}\text { Quan- } \\
\text { tity } \\
\mathrm{kg} / \mathrm{m}^{3}\end{array}$
\end{tabular} \\
\hline
\end{tabular}

Table 4 presents the summary of all the optimal quantities of binary, ternary and quaternary blended M80 grade concrete mixes. The table also displays the replacement percentages of SCMs, total powder content in $\mathrm{kg}$ and water/powder ratios along with corresponding mix numbers and mix designations

In high strength grade (M80), three optimally blended binary and ternary concrete mixes (C95+MS5, C65+FA20+MS15, C50+FA28+MS11+MK11) are chosen based on desired compressive strength achievement. From the studies, it is observed that without inclusion of micro silica (MS), desired high strength cannot be attained. Further investigations have showed that metakaolin (MK) based quaternary blended high strength concrete mix yield better performance than ternary and binary blends in terms of (1) usage of high quantity of fly ash, (2) enhanced fresh properties and (3) reduction in quantity of cement used.

From table 5.34and Fig 5.4, the total powder content for binary and ternary blended concrete mixes of high strength grade (M80) the total powder content adopted is $700 \mathrm{~kg} / \mathrm{m}^{3}$ and whereas for quaternary blended concrete mixes of M80 grade, the total powder 
content adopted is 910 (additionally $30 \%$ of FA is added). It can be concluded that quaternary blended concrete mixes are more efficient that ternary blended concrete mixes for high strength grade (M80).

Based on the compressive strength attained at specified age of curing, the efficacy of pozzolans are understood. In this study, pozzolans used for blended concrete mixes are Fly Ash (FA), Microsilica (MS) and Metakaolin (MK). Age of curing specified for Fly Ash (FA) blended binary, ternary and quaternary blended concrete mixes of various grades is 60 days while it is 28 days for Microsilica (MS) and Metakaolin (MK) blended concrete mixes.

Metakaolin (MK) blended concrete mixes will set relatively quickly due to its high reactivity, which also prevents bleeding and settling of aggregates.Metakaolin (MK) when compared to micro silica (MS) [10] has similar particle density and surface area but different morphology and surface chemistry. Because of its hydrophilic surface, Metakaolin (MK) is easier to disperse into wet concrete. Metakaolin (MK) can be incorporated at any stage of concrete production; it should be mixed thoroughly to achieve even distribution; intensive mixing is not necessary like micro silica (MS) based concrete

\subsection{Studies on Compressive Strength of binary, ternary and quaternary blended concrete mixes}

This investigation is carried out to study the compressive strength of binary, ternary and quaternary blended concrete mixes of high strength grade (M80) made with Fly Ash (FA), Microsilica (MS) and Metakaolin (MK) at 3,7,28 and 60days.

Table 6 presents the compressive strength of binary, ternary and quaternary blended concrete mixes of high strength grade (M80) made with Fly Ash (FA), Microsilica (MS) and Metakaolin (MK).

\section{Conclusions}

Based on the systematic and detailed experimental study conducted on high strength grade (M80) of binary , ternary and quaternary blended Concrete mixes made with fly ash (FA), microsilica (MS) and metakaolin (MK) with an aim to develop high performance concrete mixes, the following are the conclusions arrived.

1. Metakaolin blended binary, ternary and quaternary concrete mixes attain early strengths due to its inherent faster reacting capability than microsilica (MS) blended concrete mixes.

2. For development of high strength concrete mixes (M80), use of micro silica is compulsory due to its inherent high reactive property and micro-filler capacity.

3. In development of high strength (M80) grade fly ash blended concrete mixes, both metakaolin and micro silica are required to be added to leverage the benefits of micro-filler capacity of micro silica and early strength attainment of metakaolin. Addition of metakaolin (MK) to blended concrete mixes will enhance early hydration because of it high reactivity.

4. Optimally blended high strength grades M80 quaternary concrete mixes made of should be compacted $50 \% \mathrm{OPC}+28 \% \mathrm{FA}+11 \% \mathrm{MS}+11 \% \mathrm{MK}$ yields both required workability and desired compressive strengths. From this observation, it can be understood that micro silica (MS) in blended concrete mixtures imparts high strength while metakaolin (MK) inclusion enhances the usage of high quantity of fly ash in concrete mixes for superior rate of gain of strength. So it is evident that both metakaolin and micro silica are required in blended concrete mixes made with low water/powder ratio.

5. From the above observations it can be assumed for better flow and strength realization, in high strength grades (M80) blended fly ash based concrete mixes, the optimum percentage use of metakaolin is found to be $11 \%$.

6. Compressive strengths of metakaolin blended binary, ternary and quaternary concrete mixes have slightly increased than non- metakaolin blended concrete mixes. Metakaolin cementing reaction rate is very rapid, significantly increasing compressive strength before first three days, which can have various benefits in fast paced construction industry.

7. Metakaolin (MK) is highly reactive alumina silicate whereas micro silica (MS) is reactive silicate. Hence Metakaolin (MK) supplemented concrete mixes have high strengths at all ages because silica and alumina present in Metakaolin (MK) reacts with $\mathrm{CH}$ forms CSH (pozzolanic reaction) and CAH (aluminate hydration) respectively which contributes to additional strength than micro silica (MS). So quaternary blended concrete mix made with micro silica (MS) and Metakaolin (MK) has improved microstructure which is dense and impermeable.

\section{References}

[1] Caldarone, M. A, Gruber, K. A, and Burg, R. G. "HighReactivity Metakaolin: A New Generation Mineral Admixture," Concrete International, V. 16, No. 11, Nov. 1994, pp. 37-40.

[2] Caldarone, M.A, and Gruber, K. A. "High Reactivity Metakaolin - A Mineral Admixture for High-Performance Concrete," Concrete under Severe Conditions: Environment and Loading, Proceedings of the International Conference on Concrete under Severe Conditions, CONSEC 1995, Sapporo, Japan, Aug. 1995, K. Sakai, N. Banthia, and O. E. Gjorv, eds., V. 2, E\&FN Spon: Chapman \& Hall, New York, 1995, pp. 1015-1024.

[3] Zhang, M. H, and Malhotra,V.M. "Characteristics of a Thermally Activated Alumino-Silicate Pozzolanic Material and Its Use in Concrete, Cement \& Concrete Research, V. 25, No. 8, 1995, pp. 1713-1725.

[4] Thomas, M. D. A, Gruber, K. A, and Hooton, R. D. "The Use of High-Reactivity Metakaolin in High-Performance Concrete," High-Strength Concrete, Proceedings of First International Conference, A. Azizinamini, D. Darwin, and C. French, eds., ASCE, 1997, Kona, Hawaii, pp. 517-530.

[5] Balogh, A, "High-Reactivity Metakaolin," Aberdeen's Concrete Construction, V. 40, No. 7, 1995, 604 pp. 9.

[6] Dubey A, and Banthia, N, "Influence of High-Reactivity Metakaolin and Silica Fume on the Flexural Toughness of HighPerformance Steel Fiber-Reinforced Concrete," ACI Materials Journal, V. 95, No. 3, May-June 1998, pp. 284-292.

[7] Kostuch, J. A, Walters, G. V.and Jones, T. R. "HighPerformance Concrete Containing Metakaolin: A Review," Concrete 2000: Economic and Durable Construction through Excellence: Proceedings of the International Conference, Dundee, Scotland, Sept. 1993, R. K. Dhir and M. R. Jones, eds., 1993, pp. 1799-1811.

[8] Walters, G. V, and Jones, T. R. "Effect of Metakaolin on AlkaliSilica Reaction (ASR) in Concrete Manufactured with Reactive Aggregate," Durability of Concrete, Second International Conference, SP-126, V. M. Malhotra, ed., V. 2, American Concrete Institute, Farmington Hills, Mich., 1991, pp. 941-953.

[9] Ambroise, J, Maximilien, S, and Pera, J. "Properties of Metakaolin Blended Cements," Journal of Advanced Cement-Based Materials, V. 1, No. 4, 1994, pp. 161-168.

[10] Coleman, N.J, and McWhinnie, W. R. "Solid State Chemistry of Metakaolin-Blended Ordinary Portland Cement," Journal of Materials Science, V. 35, (11) 2000, pp. 2701-2710. 
Table 4- Trail mixes of high strength grade (M80) blended concrete mixes

\begin{tabular}{|c|c|c|c|c|c|c|c|c|c|c|c|c|c|}
\hline \multirow{2}{*}{$\begin{array}{l}\text { Mix } \\
\text { No. }\end{array}$} & \multirow{2}{*}{$\begin{array}{l}\text { Mix Designation } \\
\text { (Values indicate percentage by } \\
\text { weight of ' } \mathrm{P} \text { ' }\end{array}$} & \multicolumn{4}{|c|}{$\begin{array}{l}\text { Replacement \% } \\
\text { (bwp)* }\end{array}$} & \multirow{2}{*}{$\begin{array}{l}\text { Addi- } \\
\text { tional } \\
\% \quad \text { of } \\
\text { FA } \\
\text { bwp* }\end{array}$} & \multicolumn{4}{|c|}{$\begin{array}{l}\text { Quantities } \\
\text { kg per cu.m }\end{array}$} & \multirow{2}{*}{$\begin{array}{l}\text { Total } \\
\text { Pow- } \\
\text { der } \\
\text { Con- } \\
\text { tent } \\
\text { 'P' }\end{array}$} & \multirow{2}{*}{$\begin{array}{l}\text { Slump } \\
\text { mm }\end{array}$} & \multirow{2}{*}{$\begin{array}{l}\text { Achieved } \\
\text { Strength } \\
(\mathrm{MPa})\end{array}$} \\
\hline & & OPC & FA & MS & MK & & OPC & FA & MS & MK & & & \\
\hline $\mathrm{C} 1$ & C100 & 100 & - & - & - & - & 700 & 0 & - & - & 700 & 50 & 72.35 \\
\hline B1 & C65+FA35 & 65 & 35 & - & - & - & 450 & 250 & - & - & 700 & 66 & 58.94 \\
\hline B2 & C95+MS5 & 95 & - & 5 & - & - & 665 & - & 35 & - & 700 & 50 & 108.56 \\
\hline B3 & C90+MS10 & 90 & - & 10 & - & - & 630 & - & 70 & - & 700 & 31 & 106.04 \\
\hline B4 & C85+MS15 & 85 & - & 15 & - & - & 595 & - & 105 & - & 700 & 18 & 88.32 \\
\hline B5 & C95+MK5 & 95 & - & - & 5 & - & 665 & - & - & 35 & 700 & 54 & 72,15 \\
\hline B6 & C90+MK10 & 90 & - & - & 10 & - & 630 & - & - & 70 & 700 & 46 & 75.78 \\
\hline B7 & C85+MK15 & 85 & - & - & 15 & - & 595 & - & - & 105 & 700 & 37 & 78.82 \\
\hline B8 & C80+MK20 & 80 & - & - & 20 & - & 560 & - & - & 140 & 700 & 48 & 69.35 \\
\hline T1 & C65+FA30+MS5 & 65 & 30 & 5 & - & - & 455 & 210 & 35 & - & 700 & 55 & 81.23 \\
\hline $\mathrm{T} 2$ & C65+FA25+MS10 & 65 & 25 & 10 & - & - & 455 & 175 & 70 & - & 700 & 55 & 94.20 \\
\hline T3 & C65+FA20+MS15 & 65 & 20 & 15 & - & - & 455 & 140 & 105 & - & 700 & 55 & 100.54 \\
\hline T4 & C65+FA15+MS20 & 65 & 15 & 20 & - & - & 455 & 105 & 140 & - & 700 & 46 & 78.91 \\
\hline T5 & C65+FA30+MK5 & 65 & 30 & - & 5 & - & 455 & 210 & - & 35 & 700 & 54 & 76.23 \\
\hline T6 & C65+FA25+MK10 & 65 & 25 & - & 10 & - & 455 & 175 & - & 70 & 700 & 52 & 77.34 \\
\hline $\mathrm{T7}$ & C65+FA20+MK15 & 65 & 20 & - & 15 & - & 455 & 140 & - & 105 & 700 & 51 & 78.12 \\
\hline T8 & C65+FA15+MK20 & 65 & 15 & - & 20 & - & 455 & 105 & - & 140 & 700 & 43 & 67.21 \\
\hline Q1 & C65+FA21+MS7+MK7 & 65 & 21 & 7 & 7 & - & 455 & 147 & 49 & 49 & 700 & 44 & 90.88 \\
\hline Q2 & C60+FA28+MS6+MK6 & 65 & 21 & 7 & 7 & 10 & 455 & 217 & 49 & 49 & 770 & 54 & 82.34 \\
\hline Q3 & C54+FA34+MS6+MK6 & 65 & 21 & 7 & 7 & 20 & 455 & 287 & 49 & 49 & 840 & 55 & 72.17 \\
\hline Q4 & C65+FA14+MS14+MK7 & 65 & 14 & 14 & 7 & - & 455 & 98 & 98 & 49 & 700 & 41 & 80.16 \\
\hline Q5 & C59+FA22+MS13+MK6 & 65 & 14 & 14 & 7 & 10 & 455 & 168 & 98 & 49 & 770 & 54 & 81.23 \\
\hline Q6 & C54+FA28+MS12+MK6 & 65 & 14 & 14 & 7 & 20 & 455 & 238 & 98 & 49 & 840 & 54 & 83.65 \\
\hline Q7 & C50+FA34+MS11+MK5 & 65 & 14 & 14 & 7 & 30 & 455 & 308 & 98 & 49 & 910 & 55 & 71.37 \\
\hline Q8 & C65+FA7+MS14+MK14 & 65 & 7 & 14 & 14 & - & 455 & 49 & 98 & 98 & 700 & 33 & 90.94 \\
\hline Q9 & C58+FA16+MS13+MK13 & 65 & 7 & 14 & 14 & 10 & 455 & 119 & 98 & 98 & 770 & 52 & 93.25 \\
\hline Q10 & C53+FA23+MS12+MK12 & 65 & 7 & 14 & 14 & 20 & 455 & 189 & 98 & 98 & 840 & 54 & 94.72 \\
\hline Q11 & C50+FA28+MS11+MK11 & 65 & 7 & 14 & 14 & 30 & 455 & 259 & 98 & 98 & 910 & 55 & 110.71 \\
\hline Q12 & C46+FA34+MS10+MK10 & 65 & 7 & 14 & 14 & 40 & 455 & 329 & 98 & 98 & 980 & 56 & 79.91 \\
\hline
\end{tabular}

Table 5 - Final optimized mix proportions of blended concrete mixes

\begin{tabular}{|c|c|c|c|c|c|c|c|c|c|c|c|c|c|c|c|c|}
\hline \multirow[b]{2}{*}{$\begin{array}{l}\text { Gradeof } \\
\text { concrete } \\
\text { Mix }\end{array}$} & \multirow[b]{2}{*}{ Mix No } & \multirow[b]{2}{*}{$\begin{array}{l}\text { Mix Designation } \\
\text { (Values indicate } \\
\text { percentage by } \\
\text { weight of ' } P \text { ' }\end{array}$} & \multicolumn{4}{|c|}{$\begin{array}{l}\text { Replacement \% } \\
\text { (bwp)* }\end{array}$} & \multirow[b]{2}{*}{$\begin{array}{l}\text { Additional } \\
\% \text { of FA } \\
\text { bwp* }\end{array}$} & \multicolumn{9}{|c|}{$\begin{array}{l}\text { Quantities } \\
\text { kg per cu.m }\end{array}$} \\
\hline & & & $\mathrm{OPC}$ & FA & MS & MK & & $\begin{array}{l}\text { OPC } \\
\text { (i) }\end{array}$ & $\begin{array}{l}\text { FA } \\
\text { (ii) }\end{array}$ & $\begin{array}{l}\text { MS } \\
\text { (iii) }\end{array}$ & $\begin{array}{l}\text { MK } \\
\text { (iv) }\end{array}$ & $\begin{array}{l}\text { Total } \\
\text { Powder } \\
\text { Content } \\
\text { ‘P' kg } \\
\text { (i)+(ii)+ } \\
\text { (iii)+(iv) }\end{array}$ & $\begin{array}{l}\text { Fine } \\
\text { Aggregate }\end{array}$ & $\begin{array}{l}\text { Coarse } \\
\text { Aggregate }\end{array}$ & Water & $\begin{array}{l}\mathrm{W} / \mathrm{P} \\
\text { ratio }\end{array}$ \\
\hline \multirow{3}{*}{ M80 } & B2 & C95+MS5 & 95 & - & 5 & - & F & 665 & - & 35 & F & 700 & 644 & 966 & 150 & 0.23 \\
\hline & T3 & C65+FA20+MS15 & 65 & 20 & 15 & - & - & 455 & 140 & 105 & - & 700 & 644 & 966 & 150 & 0.23 \\
\hline & Q11 & $\begin{array}{l}\text { C50+FA28+ } \\
\text { MS11+MK11 }\end{array}$ & 65 & 7 & 14 & 14 & 30 & 455 & 259 & 98 & 98 & 910 & 644 & 658 & 150 & 0.23 \\
\hline
\end{tabular}

bwp* - By weight of Total Powder Content

W/P ratio - Water/Powder Ratio

Table 6 - Compressive Strengths of optimally blended M80 grade concrete mixes

\begin{tabular}{|c|c|c|c|c|c|c|}
\hline \multirow{2}{*}{ Grade of concrete Mix } & \multirow{2}{*}{ Mix No } & \multirow{2}{*}{$\begin{array}{l}\text { Mix Designation } \\
\text { (Values indicate percentage } \\
\text { by weight of Total Powder) }\end{array}$} & \multicolumn{4}{|c|}{$\begin{array}{l}\text { Compressive Strength } \\
\text { (MPa) }\end{array}$} \\
\hline & & & $\begin{array}{c}3 \\
\text { days }\end{array}$ & $\begin{array}{c}7 \\
\text { Days }\end{array}$ & $\begin{array}{c}28 \\
\text { days }\end{array}$ & $\begin{array}{c}60 \\
\text { days }\end{array}$ \\
\hline \multirow{3}{*}{ M80 } & B2 & C95+MS5 & 35.43 & 57.56 & 108.56 & 111.22 \\
\hline & T3 & C65+FA20+MS15 & 26.18 & 50.12 & 73.17 & 100.54 \\
\hline & Q11 & C50+FA28+MS11+MK11 & 50.02 & 64.19 & 95.26 & 110.71 \\
\hline
\end{tabular}

